\title{
Study of a combined heterotrophic and sulfur autotrophic denitrification technology for removal of nitrate in water
}

\author{
Huijuan Liu ${ }^{\mathrm{a}}$, Wei Jiang ${ }^{\mathrm{a}}$, Dongjin Wan ${ }^{\mathrm{a}, \mathrm{b}}$, Jiuhui $\mathrm{Qu}^{\mathrm{a}, *}$ \\ a State Key Laboratory of Environmental Aquatic Chemistry, Research Center for Eco-Environmental Science, Chinese Academy of Science, Beijing 100085, China \\ ${ }^{\mathrm{b}}$ Graduate School of Chinese Academy of Sciences, Beijing 100039, China
}

\section{A R T I C L E I N F O}

Article history:

Received 18 July 2008

Received in revised form 11 February 2009

Accepted 11 March 2009

Available online 21 March 2009

\section{Keywords:}

Heterotrophic denitrification

Sulfur autotrophic denitrification

Combined reactor

Drinking water

\begin{abstract}
A B S T R A C T
A combined two-step process of heterotrophic denitrification in a fluidized reactor and sulfur autotrophic denitrification processes (CHSAD) was developed for the removal of nitrate in drinking water. In this process, the advantage of high efficiency of heterotrophic denitrification with non-excessive methanol and the advantage of non-pollution of sulfur autotriphic denitrification were integrated in this CHSAD process. And, this CHSAD process had the capacity of $\mathrm{pH}$ balance and could control the concentration of $\mathrm{SO}_{4}{ }^{2-}$ in effluent by adjusting the operation condition. When the influent nitrate was $30 \mathrm{mg} \mathrm{NO}{ }^{-}{ }^{-} \mathrm{N} / \mathrm{L}$, the reactor could be operated efficiently at the hydraulic retention time (HRT) ranging from 20 to 40 min with C:N ratio (mg CH $\mathrm{CH}_{3} \mathrm{OH}: \mathrm{mg} \mathrm{NO}_{3}{ }^{-} \mathrm{N}$ ) of 2.0 (methanol as carbon source). The nitrate removal was nearly $100 \%$ and there was no accumulated nitrite or residual methanol in the effluent. The effluent $\mathrm{pH}$ was about 7.5 and the sulfate concentration was lower than $130 \mathrm{mg} / \mathrm{L}$. The maximum volume-loading rate of the reactor was $2.16 \mathrm{~kg} \mathrm{NO}_{3}{ }^{-}-\mathrm{N} /\left(\mathrm{m}^{3} \mathrm{~d}\right)$. The biomass and scanning electron microscopy graphs of biofilm were also analyzed.
\end{abstract}

(C) 2009 Elsevier B.V. All rights reserved.

\section{Introduction}

Nitrate is a wide spread contaminant of ground and surface waters due to excessive use of nitrogenous fertilizer in agricultural industry and inappropriate disposal of untreated sanitary and industrial wastes [1]. Nitrate can cause methemoglobinemia when ingested by infants, and could cause carcinoma, malformation and mutation when transformed into nitrosoamines [2-4]. The ground water from 10 to $25 \%$ of the water-supply wells in large region of the US exceeds the maximum contaminant level (MCL) for nitrate ( $10 \mathrm{mg} \mathrm{NO}_{3}{ }^{-}-\mathrm{N} / \mathrm{L}$ ) [5]. In China, the pollution of nitrate in ground water is more severe. The nitrate concentration of groundwater in some rural areas exceeds $130 \mathrm{mg} \mathrm{NO}_{3}{ }^{-}-\mathrm{N} / \mathrm{L}$. Ground water is a universal, and in some cases exclusive, drinking-water source used by both humans and livestock in rural and suburban areas. Therefore, the remediation of nitrate-contaminated groundwater is one of the targets urgently confronted.

Current chemical technologies for removal of nitrate like ion exchange and reverse osmosis are not selective to nitrate, generate secondary brine wastes and require generation of used medium [6]. Biological denitrification technology, which comprises heterotrophic denitrification [7-11] or autotrophic denitrification

\footnotetext{
* Corresponding author. Tel.: +86 1062849151 ; fax: +86 1062923558.

E-mail addresses: hjliu@rcees.ac.cn (H. Liu), Jiangwei@hotmail.com (W. Jiang), dongjin1096@yahoo.com.cn (D. Wan),jhqu@rcees.ac.cn (J. Qu).
}

[12-19], is one of the most efficient methods for nitrates removal from water. The heterotrophic denitrification system uses organic compounds, such as methanol [7-9] and ethanol [10,11], as carbon source. Its main advantages are high denitrifying rate and treatment capacity. However, nitrite will be produced and accumulated in water when the added organic is stoichiometrically insufficient [9]. Contrarily, the residual organic compound will pollute the treated water when the added organic is excessive [10].

As for autotrophic denitrification, both elemental sulfur [12-17] and hydrogen gas $[18,19]$ can be used as ideal electron donor. Sulfur limestone autotrophic denitrification (SLAD) systems have been studied widely in Europe and USA. In such process, elemental sulfur is used as electron donor while limestone is used to adjust the $\mathrm{pH} .7 .54 \mathrm{mg} / \mathrm{L}$ sulfate will be produced when $1 \mathrm{mg} \mathrm{NO}_{3}{ }^{-}-\mathrm{N} / \mathrm{L}$ is removed. There will be an increase in hardness in the treated water because $\mathrm{Ca}^{2+}$ is added due to the $\mathrm{pH}$ adjustment by limestone [20].

In order to take full advantage of heterotrophic denitrification and sulfur autotrophic denitrification, a new combined two-step process of heterotrophic and sulfur autotrophic denitrification processes (CHSAD) was developed. In the CHSAD reactor, nitrate is firstly reduced in $\mathrm{H}$ part, and the residual subsequently is reduced in $\mathrm{S}$ part. In $\mathrm{H}$ part, the nitrate is denitrified by heterotrophic denitrification when methanol was dosed as organic carbon sources. $\mathrm{H}^{+}$ was consumed. The reaction is shown in Eq. (1) [21]:

$$
\begin{aligned}
\mathrm{NO}_{3}{ }^{-} & +1.08 \mathrm{CH}_{3} \mathrm{OH}+\mathrm{H}^{+} \rightarrow 0.065 \mathrm{C}_{5} \mathrm{H}_{7} \mathrm{NO}_{2}+0.467 \mathrm{~N}_{2} \\
& +0.76 \mathrm{CO}_{2}+2.44 \mathrm{H}_{2} \mathrm{O}
\end{aligned}
$$




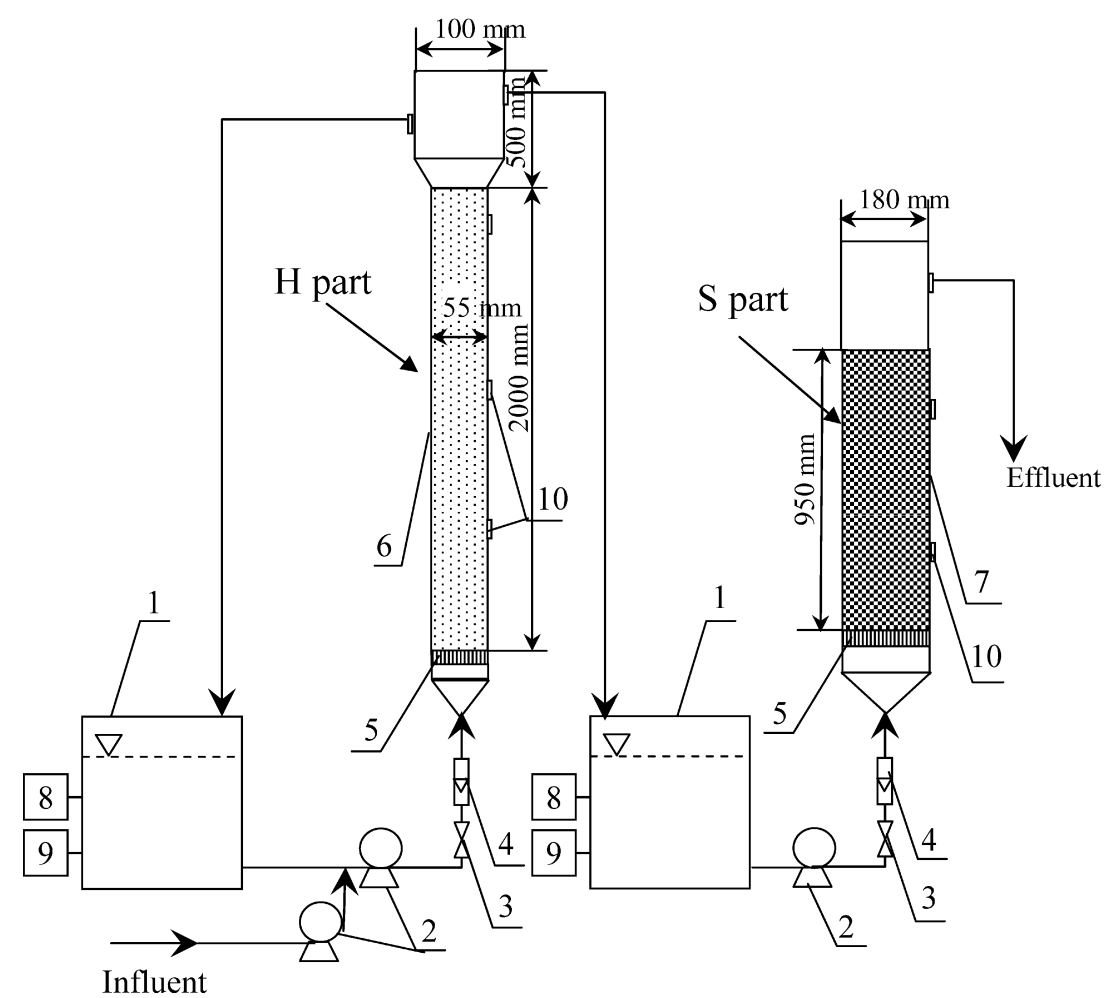

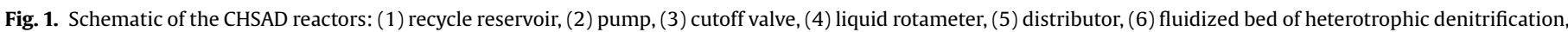
(7) bed of sulfur autotrophic denitrification, (8) temperature control system, (9) pH analyzer, and (10) sampling sites.

The stoichiometric ratio of $\mathrm{C}: \mathrm{N}\left(\mathrm{mg} \mathrm{CH}{ }_{3} \mathrm{OH}: \mathrm{mg} \mathrm{NO}_{3}{ }^{-}-\mathrm{N}\right)$ for complete denitrification using methanol as organic carbon source was 2.47 according to the reaction. In the practical process, the $\mathrm{C}: \mathrm{N}$ ratio will be higher than 2.47 due to the presence of oxygen in the water. The bacteria will consume some methanol as shown in reaction (2)

$$
\begin{aligned}
\mathrm{O}_{2} & +0.93 \mathrm{CH}_{3} \mathrm{OH}+0.056 \mathrm{NO}_{3}{ }^{-}+0.056 \mathrm{H}^{-}=0.05 \mathrm{C}_{5} \mathrm{H}_{7} \mathrm{NO}_{2} \\
& +0.65 \mathrm{CO}_{2}+1.69 \mathrm{H}_{2} \mathrm{O}
\end{aligned}
$$

In this study, the feed DO was normally below $0.5 \mathrm{mg} / \mathrm{L}$, and was controlled below $1 \mathrm{mg} / \mathrm{L}$ because the nitrogen gas was purged in the experiments.

The advantage of heterotrophic denitrification is its higher efficiency, while the disadvantage is the secondary pollution from the residual methanol. In addition, the $\mathrm{pH}$ will increase according to Eq. (1). Denitrification technologies will have to be developed so that the ratio of $\mathrm{CH}_{3} \mathrm{OH}$ to $\mathrm{NO}_{3}{ }^{-}-\mathrm{N}$ is below 2.47 for the complete removal of the residual nitrate. In this study, we combined the heterotrophic denitrification with sulfur autotrophic denitrification. In $S$ part, the autotrophic denitrification took place as shown in Eq. (3). In this process, $\mathrm{SO}_{4}{ }^{2-}$ and $\mathrm{H}^{+}$will be produced [17].

$$
\begin{aligned}
& 1.06 \mathrm{NO}_{3}{ }^{-}+1.11 \mathrm{~S}+0.3 \mathrm{CO}_{2}+0.785 \mathrm{H}_{2} \mathrm{O} \\
& \rightarrow 0.06 \mathrm{C}_{5} \mathrm{H}_{7} \mathrm{O}_{2} \mathrm{~N}+0.5 \mathrm{~N} 2+1.11 \mathrm{SO}_{4}{ }^{2-}+1.16 \mathrm{H}^{+}
\end{aligned}
$$

It can be seen from Eq. (1) that $1.0 \mathrm{~mol} \mathrm{H}^{+}$would be consumed in $\mathrm{H}$ part when $1 \mathrm{~mol} \mathrm{NO}_{3}{ }^{-}-\mathrm{N}$ was denitrified, and as a result the $\mathrm{pH}$ in effluent will decrease. On the other hand, $1.09 \mathrm{~mol} \mathrm{H}^{+}$will be provided when $1 \mathrm{molNO}_{3}{ }^{-}-\mathrm{N}$ is reduced to nitrogen gas according to Eq. (3). Thus the $\mathrm{pH}$ can be better maintained. The combined technology could achieve high nitrate removal efficiency, no residual methanol and no nitrite accumulation. In addition, the concentration of $\mathrm{SO}_{4}{ }^{2-}$ will be controlled by adjusting the nitrate load proportion of $\mathrm{H}$ part and $\mathrm{S}$ part.
Only very few studies [22-24] focus on combined heterotrophic and autotrophic process for waste water denitrification. For drinking water, there was no report on combined heterotrophic and autotrophic denitrification process. Therefore, the main objectives of this research are (1) to develop the CHSAD process; (2) to verify the feasibility of this process; and (3) to present the applicable operation conditions of this process for nitrate removal from water.

\section{Materials and methods}

\subsection{Experimental set-up}

Experiments were performed in the apparatus shown in Fig. 1. The reactor consisted of $\mathrm{H}$ part and $\mathrm{S}$ part, and the total effective liquid volume of the reactor was $19.6 \mathrm{~L}$.

The fluidized bed in $\mathrm{H}$ part constructed from the plexiglas had an i.d. of $55 \mathrm{~mm}$ and a height of $2000 \mathrm{~mm}$. It was ended by a disengaging cap with an i.d. of $100 \mathrm{~mm}$ and a height of $500 \mathrm{~mm}$. Anthracite (Gongyi, China) with a diameter of $1.0-1.2 \mathrm{~mm}$ was used as carriers for the microorganisms. The effective volume of $\mathrm{H}$ part was $4 \mathrm{~L}$.

$S$ part included a cylindrical plexiglas with an i.d. of $180 \mathrm{~mm}$ and a height of $2400 \mathrm{~mm}$; its effective volume was $15.6 \mathrm{~L}$. Sulfur granules obtained from Luoyang Sunrise Industrial of China had a diameter of 5-7 mm. The height of the sulfur granules packed bed was $950 \mathrm{~mm}$. The liquid flow rate measured with a rotameter was controlled by a cutoff valve. The temperature was controlled by an electric heater coupled with a contact thermometer.

The synthetic water with $30 \mathrm{mg} \mathrm{NO}_{3}{ }^{-}-\mathrm{N} / \mathrm{L}$ as an influent in our study was prepared by the water from the 9th Beijing Water Treatment Plant and certain amount of $\mathrm{NaNO}_{3}$. The water had IC (inorganic carbon) of $8 \mathrm{mgC} / \mathrm{L}, \mathrm{SO}_{4}{ }^{2-}$ concentration of about $40 \mathrm{mg} / \mathrm{L}$ and $\mathrm{pH}$ of 7.6. All chemicals used in this experiment were analytical grade (Beijing Agent Plant, Beijing, China). The influent was first pumped from feed tank to $H$ part and then to $S$ part; the flow rate ranged from 2 to $12 \mathrm{~L} / \mathrm{h}$. The feed was purged with 
nitrogen gas in order that the DO level was below $0.5 \mathrm{mg} / \mathrm{L}$. All the experiments were conducted at a room temperature of $20-25^{\circ} \mathrm{C}$.

\subsection{Experimental design}

The whole experiment included three stages: pre-inoculation stage, inoculation-acclimation stage and operation stage. All the data in this study were the averaged values of the three sequential samples and the error was within $5 \%$.

\subsubsection{Inoculation and acclimation}

For the inoculation and acclimation of $\mathrm{H}$ part, bacterium seed was obtained from the effluent of a heterotrophic denitrification system in our laboratory. The bacterium carrier of anthracite with a diameter of $1.0-1.2 \mathrm{~mm}$ was first dipped into the effluent for inoculation. After 2 days of inoculation, the anthracite was filled into the $\mathrm{H}$ part column. The influent, in which the $\mathrm{CH}_{3} \mathrm{OH}$ and $\mathrm{NO}_{3}{ }^{-}-\mathrm{N}$ ratio was 3:1 was delivered to the reactor by a pump. The $\mathrm{pH}$ was kept neutral by buffering solution of $30 \mathrm{mg} / \mathrm{L} \mathrm{K}_{2} \mathrm{HPO}_{4}$ and $10 \mathrm{mg} / \mathrm{L}$ $\mathrm{KH}_{2} \mathrm{PO}_{4}$. Under the continuous flow condition, the biofilm was formed on the anthracite surface in about 20 days.

The bacterium seed for S part was obtained from an effluent of a heterotrophic denitrification system and acclimated to complete autotrophic denitrification. Under the continuous-flow condition, the biofilm was cultured on the sulfur granule surface in 20 days with $\mathrm{CH}_{3} \mathrm{OH}$ and $\mathrm{NO}_{3}{ }^{-}-\mathrm{N}$ ratio of 3.0 in the influent. The neutral $\mathrm{pH}$ was kept by a buffering solution consisted of $30 \mathrm{mg} / \mathrm{L} \mathrm{K}_{2} \mathrm{HPO}_{4}$ and $10 \mathrm{mg} / \mathrm{L} \mathrm{KH}_{2} \mathrm{PO}_{4}$. After the biofilm was formed, the ratio of $\mathrm{CH}_{3} \mathrm{OH}$ to $\mathrm{NO}_{3}{ }^{-}-\mathrm{N}$ decreased gradually from $3: 1$ to $2: 1,1.5: 1,1: 1$, and finally $0: 1$. The reactor was stabilized for 10 days for each condition. Thus, biofilm was formed on the surface of the sulfur particles, and $S$ part was acclimated to complete autotrophic denitrification. When the denitrification rate became stable, the $\mathrm{pH}$ buffering system was removed and the batch experiments were started.

\subsubsection{Operation stage}

First, the applicable operation conditions of $\mathrm{H}$ part were determined at the operation stage. $\mathrm{H}$ part was tested at $\mathrm{C}: \mathrm{N}$ ratio of 3.0, 2.47 and 2.0. At each $\mathrm{C}: \mathrm{N}$ ratio, different hydraulic retention time (HRT) was applied to the reactor sequentially. Under different C:N ratios and HRT, the system was run for 2 days in order that it became stabilized. The system was not considered in quasi-steady-state condition until the sample data $\left(\mathrm{NO}_{3}{ }^{-}-\mathrm{N}, \mathrm{NO}_{2}{ }^{-}-\mathrm{N}\right.$, and concentration of $\mathrm{CH}_{3} \mathrm{OH}$ ) variation of sequential retention times was less than $5 \%$. Under quasi-steady-state condition, the corresponding experiments or measurements were conducted.

After the applicable condition was confirmed in $\mathrm{H}$ part, the combined reactor-CHSAD process was performed to confirm it applicability for nitrate removal in drinking water. In this stage, the $\mathrm{pH}$ and the concentration of $\mathrm{SO}_{4}{ }^{2-}$ of the effluent were also considered.

\subsection{Analytical methods}

The $\mathrm{NO}_{3}{ }^{-}-\mathrm{N}, \mathrm{NO}_{2}{ }^{-}-\mathrm{N}, \mathrm{SO}_{4}{ }^{2-}, \mathrm{pH}$, methanol, total organic carbon (TOC) of the influent, $\mathrm{H}$ part and $\mathrm{S}$ part effluent were measured. Samples were filtered through $0.45 \mu \mathrm{m}$ membrane for $\mathrm{NO}_{3}{ }^{-}-\mathrm{N}, \mathrm{NO}_{2}{ }^{-}-\mathrm{N}$, methanol, $\mathrm{SO}_{4}{ }^{2-}$ and $\mathrm{TOC}$ analysis. The $\mathrm{NO}_{3}{ }^{-}-\mathrm{N}$, $\mathrm{NO}_{2}{ }^{-}-\mathrm{N}, \mathrm{SO}_{4}{ }^{2-}$ were measured by ion chromatograph (Dionex4500 i, Dionex Inc., Sunnyvale, CA, USA). Concentration of methanol was analyzed by off-color acid method. The $\mathrm{pH}$ was measured using a 9165BN pH electrode connected to Orion-828 pH Analyzer (Orion Research Inc., Beverly, MA, USA). TOC was measured by a TOC analyzer (Model Applo 9000, Tekmar Dohrmann Inc., Mason, OH, USA). The detection limits of nitrate, nitrite, sulfate and TOC were $0.1,0.1$, 0.2 and $0.1 \mathrm{mg} / \mathrm{L}$, respectively.
Biological mass on surface of the anthracite in the fluidized bed was analyzed according to the method of Liu [25]. The $50 \mathrm{~mL}$ samples of anthracite particles for biological mass measurement were taken from the sampling sites of 0.8 and $1.2 \mathrm{~m}$ above the bottom bed, respectively. The samples preparation for scanning electron microscopy (SEM) was carried out as follows. The granules were put into 50 - $\mathrm{mL}$ serum bottle containing $4 \%$ glutaraldehyde in $0.05 \mathrm{~mol} / \mathrm{L}$ cacodylate buffer, then the bottle was sealed. Fixation was carried out for $12 \mathrm{~h}$ at $4{ }^{\circ} \mathrm{C}$. The fixed granules were washed with phosphoric acid buffer ( $1: 1)$ for three times, and then fixed with $1 \%$ osmium tetroxide. The granules were then dehydrated with a graded series of ethanol in distilled water from $50 \%$ to $100 \%(\mathrm{v} / \mathrm{v})$ and replaced by tert-amyl acetate. The specimens were dried in $\mathrm{CO}_{2}$ critical point dryer (SPI Inc., PA, USA), mounted on brass discs, and sputter coated in Eilo Ion Coater (model IB-3, Hatachi Inc., Naka, Japan) with platinum/palladium target (60/40). The prepared specimens were examined (HITACHI S-570 SEM, Hatachi Inc., Naka, Japan) at an accelerating voltage of $12 \mathrm{kV}$.

\section{Results and discussion}

\subsection{Influence of C:N ratio on the nitrate removal in $H$ part}

The majority of biodenitrification relies on heterotrophic bacteria that require an organic carbon source. Since drinking water has low carbon content, an additional carbon source is required. The $\mathrm{C}: \mathrm{N}$ ratio is a key factor influencing the efficiency of denitrification. In order to obtain the applicable operation parameters in combining with $\mathrm{S}$ part, the effect of $\mathrm{C}: \mathrm{N}$ ratio on the nitrate removal efficiency, the $\mathrm{pH}$ change, the residual methanol, and $\mathrm{NO}_{2}{ }^{-} \mathrm{N}$ accumulation were investigated in $\mathrm{H}$ part firstly. Fig. 2 represents the denitrification efficiency of $\mathrm{H}$ part as a function of HRT at C:N ratios of 3.0, 2.47, and 2.0.

As shown, the denitrification efficiency depended on both the $C: N$ ratio and the HRT. When the methanol is excessive $(C: N=3.0)$, the denitrification rate is very high and the nitrate removal efficiency reached nearly $100 \%$ at the HRT of $12 \mathrm{~min}$. When the methanol dosage is applied according to the stoichiometric ratio of $\mathrm{C}: \mathrm{N}=2.47$, the nitrate removal efficiency reaches $98 \%$ at the HRT of about $22 \mathrm{~min}$. When the methanol dose is lower than that required for the complete denitrification, the nitrate removal rate is lower than that of the $\mathrm{C}: \mathrm{N}=3.0$ and 2.47. The nitrate removal efficiency can reach about $80 \%$ when the C:N ratio is 2.0 with the HRT of $40 \mathrm{~min}$. The results show that high denitrification efficiency could be realized at an insufficient methanol dose in $\mathrm{H}$ part.

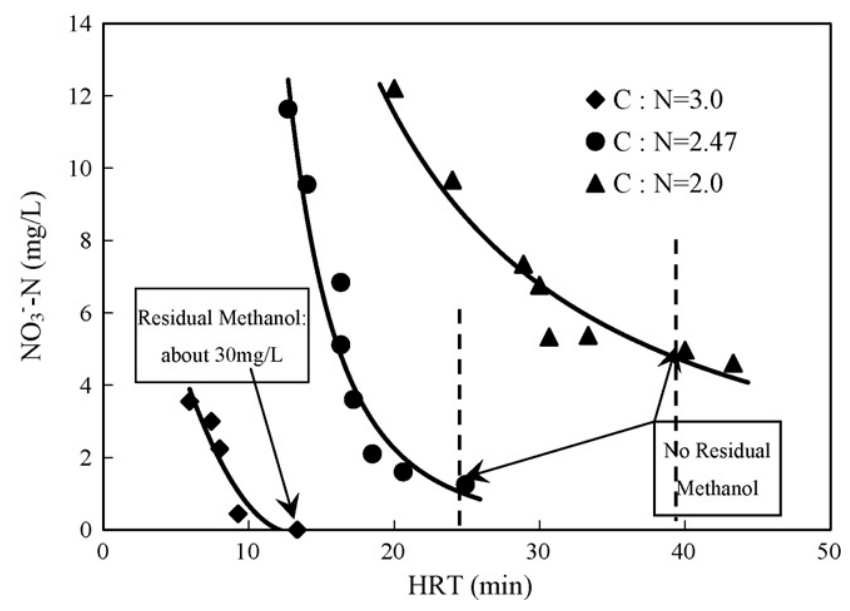

Fig. 2. Nitrate in the effluent of the $\mathrm{H}$ part as a function of HRT at different $\mathrm{C}: \mathrm{N}$ ratios. (The concentration of $\mathrm{NO}_{3}{ }^{-}-\mathrm{N}$ was $30 \mathrm{mg} / \mathrm{L}$ in influent.) 


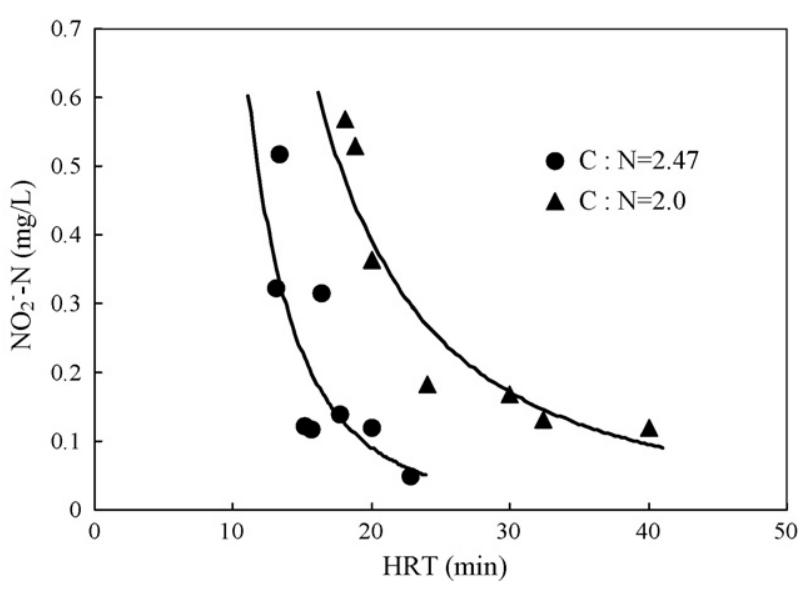

Fig. 3. Nitrite accumulation of the $\mathrm{H}$ part as a function of HRT at different $\mathrm{C}: \mathrm{N}$ ratios. (The concentration of $\mathrm{NO}_{3}{ }^{-}-\mathrm{N}$ was $30 \mathrm{mg} / \mathrm{L}$ in influent.)

The residual methanol was measured at each HRT with different $\mathrm{C}: \mathrm{N}$ ratios and showed in Fig. 2. The results show that the residual methanol is about $30 \mathrm{mg} / \mathrm{L}$ when the nitrate is reduced completely at the condition of $\mathrm{C}: \mathrm{N}$ ratio of 3.0. When the $\mathrm{C}: \mathrm{N}$ ratio is 2.47 , there is no residual methanol at the HRT of $24 \mathrm{~min}$, in that point the nitrate removal efficiency is about $98 \%$. As for the $\mathrm{C}: \mathrm{N}$ ratio of 2.0 , the no residual methanol point is found at the HRT of $40 \mathrm{~min}$, and the nitrate removal efficiency is about $80 \%$.

Usually, biological denitrification consists of a sequence of enzymatic reactions leading to the evolution of nitrogen. In this process, microorganisms first reduce nitrates to nitrites and then produce nitric oxide, nitrous oxide, and finally nitrogen gas. The pathway for nitrate reduction is given in Eq. (4):

$\mathrm{NO}_{3}{ }^{-} \rightarrow \mathrm{NO}_{2}{ }^{-} \rightarrow \mathrm{NO} \rightarrow \mathrm{N}_{2} \mathrm{O} \rightarrow \mathrm{N}_{2}$

It is reported that the limited carbon conditions would result in the increase of $\mathrm{NO}_{2}{ }^{-}-\mathrm{N}$ concentration in the effluent [9]. Fig. 3 shows the nitrite accumulation in the effluent of $\mathrm{H}$ part as a function of HRT at C:N ratios of 2.47 and 2.0 , respectively. At the $\mathrm{C}: \mathrm{N}$ ratio of 3.0, no nitrite is detected. With the increase of HRT, the nitrite accumulation decreases at the $\mathrm{C}: \mathrm{N}$ ratios of 2.47 and 2.0. As for $\mathrm{C}: \mathrm{N}=2.0$, the nitrite concentration is about $0.15 \mathrm{mg} \mathrm{NO}_{2}{ }^{-}-\mathrm{N} / \mathrm{L}$ at the HRT of $40 \mathrm{~min}$. Since the nitrite is more toxic than nitrate, the formed nitrite in $\mathrm{H}$ part must be removed by $\mathrm{S}$ part.

According to Eq. (1), the $\mathrm{pH}$ would increase after $\mathrm{H}$ part. The $\mathrm{pH}$ of the effluent was at the range of 7.9-8.2 after the heterotrophic denitrification process when the influent $\mathrm{pH}$ was about 7.5. The $\mathrm{pH}$ balance in $\mathrm{H}$ part and $\mathrm{S}$ part would be discussed subsequently.

\subsection{Nitrate removal efficiency of the CHSAD}

Since the heterotrophic denitrification has the risk of secondary pollution when using excess organic carbon, it is better to use nonexcessive organic carbon and the residual nitrate and formed nitrite are removed by $\mathrm{S}$ part. As for the $\mathrm{pH}$ balance, it can be concluded from Section 3.1 that neutral condition after the CHSAD process could be reached when the $\mathrm{H}^{+}$consumed from $\mathrm{H}$ part is off-set by that generated in $\mathrm{S}$ part. In addition, the concentration of $\mathrm{SO}_{4}{ }^{2-}$ in effluent must be considered in the operation of the CHSAD process. In order to determine the applicable operation conditions, the experiment was carried out at different HRT with C:N ratio of 2.0. As shown in Fig. 4, the combined removal efficiency is $90 \%$ at HRT of $20 \mathrm{~min}$ and reaches nearly $100 \%$ at HRT of $30 \mathrm{~min}$. H part contributes $60 \%$ and $75 \%$ removal efficiency at the HRT of 20 and $30 \mathrm{~min}$, respectively. At HRT of $20 \mathrm{~min}$, the nitrate removal ratio of $\mathrm{H}$ part and $\mathrm{S}$ part is close to $2: 1$ and higher than 1.09:1, therefore the $\mathrm{pH}$ of efflu-

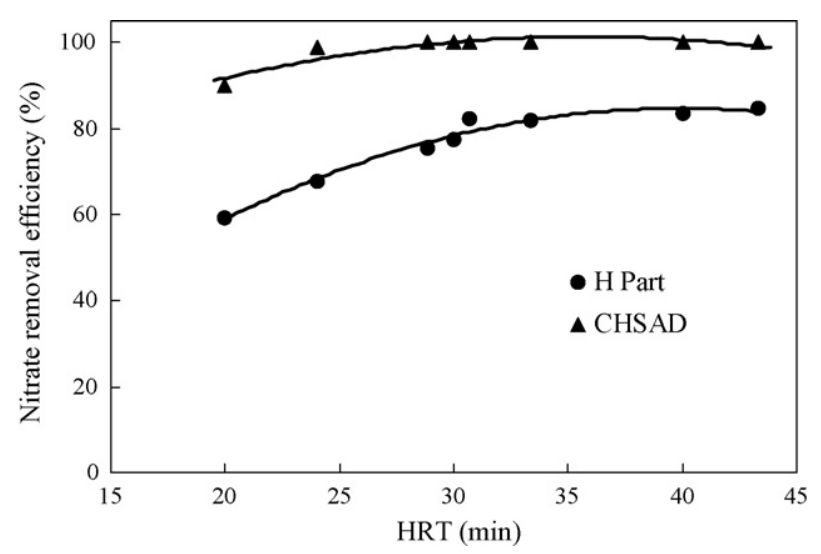

Fig. 4. Nitrate removal of the $\mathrm{H}$ part and $\mathrm{CHSAD}$ as a function of HRT at $\mathrm{C}: \mathrm{N}=2.0$. The influent nitrate concentration was kept at $30 \mathrm{mg} \mathrm{NO}_{3}{ }^{-}-\mathrm{N} / \mathrm{L}$.

ent would be slightly higher than that in the influent. The average $\mathrm{pH}$ of influent, the effluent from $\mathrm{H}$ part and CHSAD were about 7.5, 8.04, and 7.6 respectively. The results indicate that the alkalinity generated by $\mathrm{H}$ part could be greatly consumed by $\mathrm{S}$ part, and thus the $\mathrm{H}^{+}$balance could be realized during the process. The maximum volume-loading rate of the reactor was $2.16 \mathrm{~kg} \mathrm{NO}_{3}{ }^{-}-\mathrm{N} /\left(\mathrm{m}^{3} \mathrm{~d}\right)$.

\subsection{Sulfate concentration profile in the effluent}

The variation of $\mathrm{SO}_{4}{ }^{2-}$ in the effluent was given in Fig. 5. The nitrate concentration of the influent was $30 \mathrm{mg} \mathrm{NO}_{3}{ }^{-}-\mathrm{N} / \mathrm{L}$. The effluent sulfate concentration could be controlled via HRT adjustment. It can be seen that the sulfate concentration at different HRT ranges from 89 to $123 \mathrm{mg} / \mathrm{L}$, and this is below the secondary MCL level of sulfate of the US EPA $(250 \mathrm{mg} / \mathrm{L})$. The concentration ratio of sulfate to consumed $\mathrm{NO}_{3}{ }^{-}-\mathrm{N}$ is between 6.9 and 7.9 , close to the values of $6.4,7.89$, and 9.9 [20], and the stoichiometric value of 7.45. If the water is treated with $S$ part only, the concentration of $\mathrm{SO}_{4}{ }^{2-}$ in effluent will be about $260 \mathrm{mg} / \mathrm{L}$ according to the calculated stoichiometric value of 7.45 of sulfate to consumed $\mathrm{NO}_{3}{ }^{-}-\mathrm{N}$. The residual nitrate removal in $\mathrm{H}$ part leads to a low nitrate loading of $\mathrm{S}$ part, thus decreases sulfate concentration in the effluent. If the concentration of $\mathrm{SO}_{4}{ }^{2-}$ in influent is high, it can be adjusted via changing the HRT.

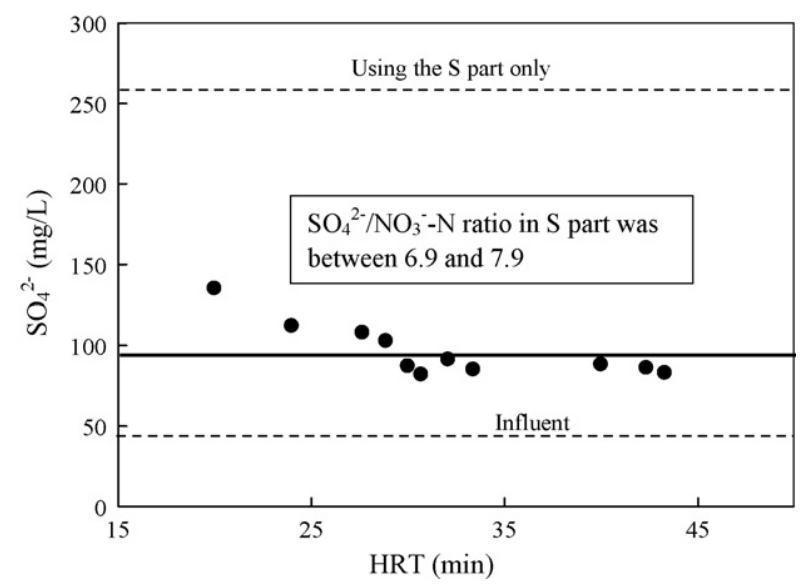

Fig. 5. Sulfate in the effluent of the CHSAD at different HRT. 
Table 1

Comparison with other denitrification systems.

\begin{tabular}{|c|c|c|c|c|c|c|c|}
\hline Reactor & Effective volume (L) & $\mathrm{H} / \mathrm{A}$ & Carbon source & Initial $\mathrm{NO}_{3}{ }^{-}-\mathrm{N}(\mathrm{mg} / \mathrm{L})$ & HRT (h) & Removal efficiency & Reference \\
\hline Membrane bioreactor & - & $\mathrm{H}$ & Methanol & 20 & 5.3 & $88.8 \%$ & [7] \\
\hline Gas-liquid-solid fluidized bed bioreactor & - & $\mathrm{H}$ & Methanol & 104.6 & 3 & $96 \%$ & [9] \\
\hline Elemental sulfur packed bed reactor & - & A & - & 60 & 4 & $96 \%$ & [17] \\
\hline Sulfur packed bed reactor & 3.38 & $\mathrm{H} \& \mathrm{~A}$ & Methanol & 750 & 2.34 & $98 \%$ & [22] \\
\hline Sulfur packed bed reactor & 3.38 & $\mathrm{H} \& \mathrm{~A}$ & $\begin{array}{l}\text { Methanol/ } \\
\text { sodium } \\
\text { acetate/glucose }\end{array}$ & $700-900$ & 6.76 & $100 \%$ & [23] \\
\hline Sulfur packed bed reactor & 0.22 & $\mathrm{H} \& \mathrm{~A}$ & Methanol & 400 & 14 & $98 \%$ & {$[24]$} \\
\hline Fluidized reactor and sulfur packed bed reactor & 19.6 & $\mathrm{H} \& \mathrm{~A}$ & Methanol & 30 & $0.33-0.50$ & $90-100 \%$ & This study \\
\hline
\end{tabular}

Note: H: heterotrophic; A: autotrophic.

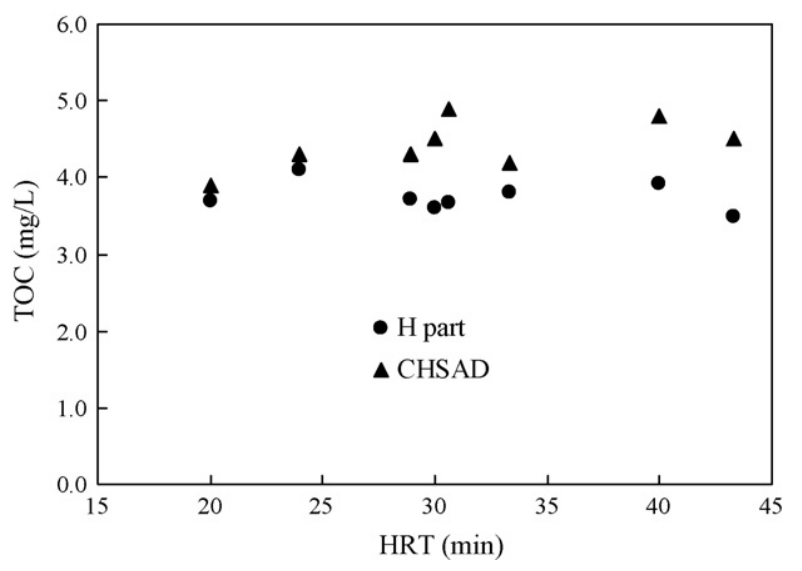

Fig. 6. TOC concentration in the effluent of the heterotrophic reactor and CHSAD as a function of HRT at $\mathrm{C}: \mathrm{N}=2.0$.

\subsection{TOC in the effluent}

Fig. 6 shows TOC concentration in the effluent of the $\mathrm{H}$ part and CHSAD as a function of HRT at $\mathrm{C}: \mathrm{N}=2.0$.

It could be seen that the TOC concentration in the effluent of the heterotrophic reactor was about $4 \mathrm{mg} / \mathrm{L}$ during the whole operation period. The TOC concentration in the effluent of the heterotrophic reactor became lower as HRT decreased with methanol consuming. The TOC concentration in the effluent of CHSAD was a little higher than that of $\mathrm{H}$ part. This was due to autotrophic processes could generate some TOC.

\subsection{Biomass analysis}

The biomass in the effluent of CHSAD was very low and did not change obviously with 1 -year operation. The variation of the COD and SS of the biomass in $\mathrm{H}$ part was analyzed. Under the condition of $\mathrm{C}: \mathrm{N}=2.0$ and HRT $=30 \mathrm{~min}$, the biomass increased with the increase of the reactor height. At the height of $0.8 \mathrm{~m}$, the COD and SS are $24.5 \mathrm{mg} \mathrm{COD} / \mathrm{cm}^{2}$ and $0.061 \mathrm{~g} \mathrm{SS} / \mathrm{cm}^{2}$, respectively, and they increase to $38.2 \mathrm{mg} \mathrm{COD} / \mathrm{cm}^{2}$ and $0.111 \mathrm{~g} \mathrm{SS} / \mathrm{cm}^{2}$ at the top of $\mathrm{H}$ part (1.6 $\mathrm{m}$ height). The above-mentioned phenomena resulted from the hydraulic washing in fluidized bed.

Fig. 7(a) and (b) shows the SEM micrographs of the cross-section of the biofilm and the anthracite surface at height of $1.6 \mathrm{~m}$, in $\mathrm{H}$ part under the condition of $\mathrm{C}: \mathrm{N}=2.0$ and HRT $=30 \mathrm{~min}$, respectively. It can be found that the surface has complex bacterial composition with some lacuna.

\subsection{Comparison with other denitrification systems}

To compare with other biological denitrification systems (including heterotrophic, sulfur autotrophic and combined reac-

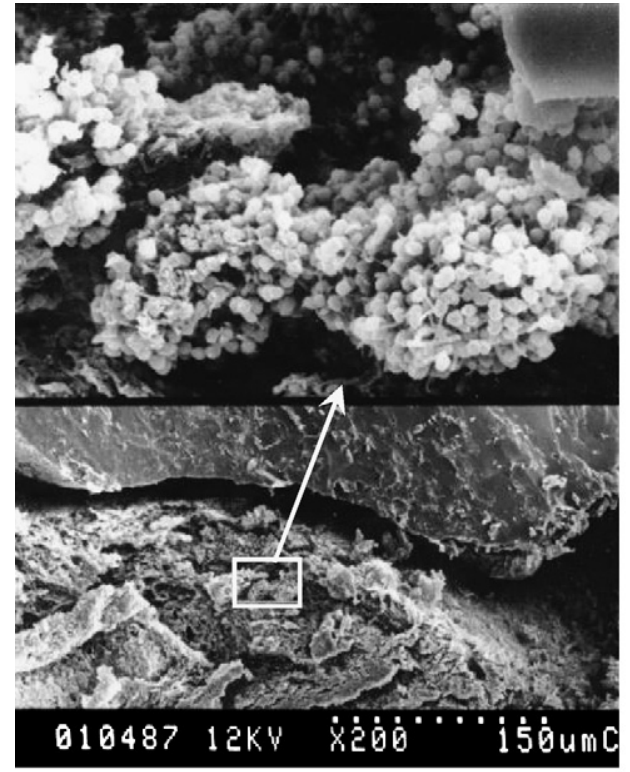

(a)

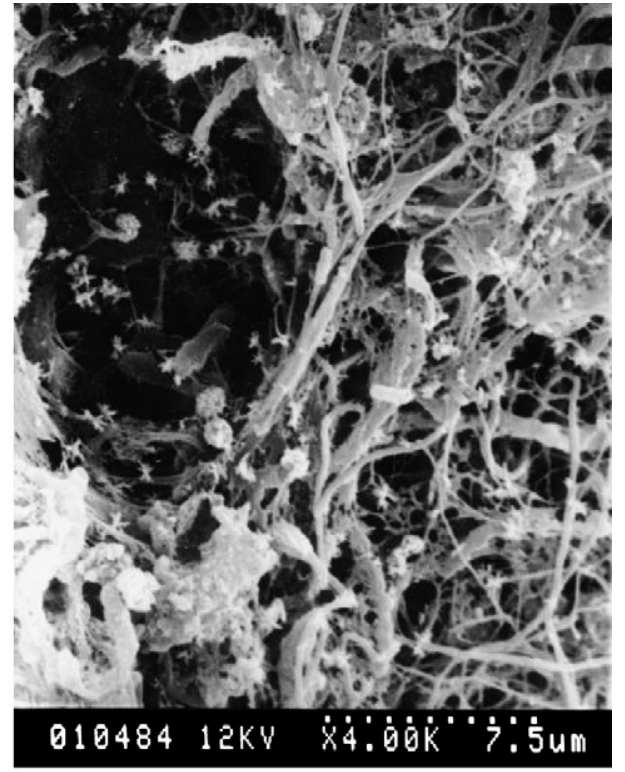

(b)

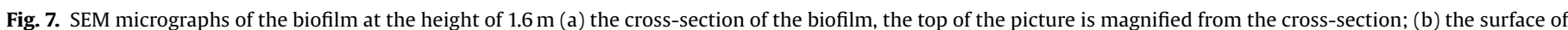
on the anthracite particle. 
tors), the main operation parameters for the best removal capacity of each reactor are summarized in Table 1.

It can be seen from Table 1 that the CHSAD system has advantages of shorter HRT, higher removal efficiency and no-organic pollution. It was favorable for nitrate removal, especially for drinking water treatment.

\section{Conclusions}

The 1-year performance of the combined reactor of heterotrophic denitrification and sulfur autotrophic denitrification was evaluated. It is clear that combining the heterotrophic and autotrophic denitrification into one process is possible for nitrate removal in drinking water treatment. High denitrification efficiency has been obtained in this integrated process. The $\mathrm{H}^{+}$consumed in $\mathrm{H}$ part can be formed in $\mathrm{S}$ part, and the $\mathrm{pH}$ adjustment was not necessary and the effluent hardness increase was avoided. Because heterotrophic denitrification has high nitrate removal efficiency even at insufficient organic carbon source, only part of the nitrate removal carried out in sulfur denitrification through HRT adjustment. Therefore, the sulfate concentration in the final effluent of CHSAD reactor was lower than that of sulfur denitrification system. The applicable HRT for the CHSAD process was from 20 to $40 \mathrm{~min}$ with the feed $\mathrm{C}: \mathrm{N}$ ratio of 2.0 and at this operation condition, the nitrate removal was higher than $90 \%$ and even up to $100 \%$ without nitrite accumulation.

\section{Acknowledgements}

This work was supported by the Fund for Creative Research Groups of China (50621804) and Hi-Tech Research and Development Program of China (2006AA06Z302).

\section{References}

[1] M.N. Almasri, J.J. Kaluarachchi, Assessment and management of long-term nitrate pollution of ground water in agriculture-dominated watersheds, J. Hydrol. 295 (2004) 225-245.

[2] E.F. Winto, Nitrate in drinking water, J. Am. Water Works Assoc. 63 (1997) 95-104.

[3] H.I. Shuval, Infant methemoglobinemia and other health effects of nitrates in drinking water, Prog. Water Technol. 12 (1980) 1731-1736.

[4] S.S. Mirvish, N-nitroso compounds, nitrate, and nitrite: possible implications for the causation of human cancer, Prog. Water Technol. 8 (1977) 195-204.
[5] B.T. Nolan, B.C. Ruddy, K.J. Hitt, D.R. Helsel, Risk of nitrate in groundwaters of the United States-a national perspective, Environ. Sci. Technol. 31 (1997) 2229-2236.

[6] S. Ghafari, M. Hasan, M.K. Aroua, Bio-electrochemical removal of nitrate from water and wastewater-a review, Bioresour. Technol. 99 (2008) 39653974.

[7] E. Wạsik, J. Bohdziewicz, M. Błaszczyk, Removal of nitrate ions from natura water using a membrane bioreactor, Sep. Purif. Technol. 22-23 (2001) 383-392.

[8] S.J. Ergas, D.E. Rheinheimer, Drinking water denitrification using a membrane bioreactor, Water Res. 38 (2004) 3225-3232.

[9] J.P. Wen, L. Pan, L.P. Du, G.Z. Mao, The denitrification treatment of low C:N ratio nitrate-nitrogen wastewater in a gas-liquid-solid fluidized bed bioreactor, Chem. Eng. J. 94 (2003) 155-159.

[10] A. Nuhoglu, T. Pekdemir, E. Yildiz, B. Keskinler, G. Akay, Drinking water denitrification by a membrane bio-reactor, Water Res. 36 (2002) 1155-1166.

[11] G. Buttiglieri, F. Malpei, E. Daverio, M. Melchiori, H. Nieman, J. Ligthart, Denitrification of drinking water sources by advanced biological treatment using a membrane bioreactor, Desalination 178 (2005) 211-218.

[12] B. Batchelor, A.W. Lawerence, Autotrophic denitrification using elemental sulfur, J. Water Pollut. Control Fed. 50 (1978) 1986-2001.

[13] K. Kimura, M. Nakamura, Y. Watanabe, Nitrate removal by a combination of elemental sulfur-based denitrification and membrane filtration, Water Res. 36 (2002) 1758-1766.

[14] R. Sierra-Alvarez, R. Beristain-Cardoso, M. Salazar, J. Gómez, E. Razo-Flores, J.A. Field, Chemolithotrophic denitrification with elemental sulfur for groundwater treatment, Water Res. 41 (2007) 1253-1262.

[15] H.S. Moon, K.H. Ahn, S. Lee, K. Nam, J.Y. Kim, Use of autotrophic sulfur-oxidizers to remove nitrate from bank filtrate in a permeable reactive barrier system, Environ. Pollut. 129 (2004) 499-507.

[16] L.H. Liu, A. Koenig, Use of limestone for $\mathrm{pH}$ control in autotrophic denitrification: batch experiments, Process Biochem. 37 (2002) 885-893.

[17] A. Koenig, L.H. Liu, Kinetic model of autotrophic denitrification in sulphur packed-bed reactors, Water Res. 35 (2001) 1969-1978.

[18] B. Rezania, J.A. Oleszkiewicz, N. Cicek, Hydrogen-dependent denitrification of water in an anaerobic submerged membrane bioreactor coupled with a novel hydrogen delivery system, Water Res. 41 (2007) 1074-1080.

[19] B.O. Mansell, E.D. Schroeder, Hydrogenotrophic denitrification in a microporous membrane bioreactor, Water Res. 36 (2002) 4683-4690.

[20] H.Y. Wang, J.H. Qu, Combined bioelectrochemical and sulfur autotrophic denitrification for drinking water treatment, Water Res. 37 (2003) 3767-3775.

[21] L. Foglar, F. Briški, Wastewater denitrification process-the influence of methanol and kinetic analysis, Process Biochem. 39 (2003) 95-103.

[22] E.W. Kim, J.H. Bae, Alkalinity requirements and the possibility of simultaneous heterotrophic denitrification during sulfur-utilizing autotrophic denitrification, Water Sci. Technol. 42 (2000) 233-238.

[23] D.U. Lee, I.S. Lee, Y.D. Chai, J.H. Bae, Effects of external carbon source and empty bed contact time on simultaneous heterotrophic and sulfur-utilizing autotrophic denitrification, Process Biochem. 36 (2001) 1215-1224.

[24] I.S. Dim, S.E. Oh, M.S. Bum, J.L. Lee, S.T. Lee, Monitoring the denitrification of wastewater containing high concentrations of nitrate with methanol in a sulfurpacked reactor, Appl. Microbiol. Biotechnol. 59 (2002) 91-96.

[25] Y. Liu, Estimating minimum fixed biomass concentration and active thickness of nitrifying biofilm, J. Environ. Eng. 123 (1997) 198-202. 